\title{
Plasticity of thermal limits in the aquatic saline beetle Enochrus politus (Küster 1849) (Coleoptera: Hydrophilidae) under changing environmental conditions
}

\author{
M. Botella-Cruz*, J. A. Carbonell, S. Pallarés, A. Millán and J. Velasco \\ Departamento de Ecología e Hidrología, Universidad de Murcia. Campus de Espinardo 30100, Murcia, España. \\ *Corresponding author: maria.botella1@um.es
}

Received: 01/04/15 Accepted: 04/09/15

\begin{abstract}
Plasticity of thermal limits in the aquatic saline beetle Enochrus politus (Küster 1849) (Coleoptera: Hydrophilidae) under changing environmental conditions

Information on the physiological tolerance of species is essential when forecasting their responses to climatic change, especially for those with restricted distributions, as well as those inhabiting extreme environments, such as inland saline waters. Temperature and salinity are expected to increase in these ecosystems under climate change, and both factors are known to affect the thermal tolerances of aquatic insects. The objective of this study was to determine, in the laboratory, the thermal limits and their plasticity to changes under the environmental conditions of the aquatic beetle Enochrus politus, a typical species of saline streams from the southeast of Spain. Supercooling temperature (point before the freezing temperature) and Heat coma (point of paralysis prior to death) were used as the lower and upper thermal limits, respectively. They were determined by a dynamic method combined with infrared thermography in groups of individuals previously acclimated at different conditions of temperature and salinity. E. politus showed a wide range of thermal tolerance $\left(-10.38 \pm 0.32{ }^{\circ} \mathrm{C}-57.37\right.$ $\pm 0.19^{\circ} \mathrm{C}$ ) and was higher in specimens acclimated at $20^{\circ} \mathrm{C}$ and $12 \mathrm{~g} / \mathrm{L}$, coinciding with the mean environmental conditions of the habitats where the species often lives. At lower temperatures and salinities, its thermal tolerance range decreased. The temperature and salinity of acclimation both had significant effects on the thermal limits. Elevated salinity decreased the heat tolerance and increased the freezing tolerance. The lower thermal limit of the species showed more plasticity than the upper limit. The species would potentially be able to tolerate temperature increase according to its wide thermal range, when compared to other insects; however, the salinization of its habitat might reduce its heat tolerance.
\end{abstract}

Key words: Saline streams, Coleoptera, thermal limits, phenotypic plasticity, Supercooling, Heat coma.

\section{RESUMEN}

Plasticidad de los límites térmicos en un escarabajo acuático, Enochrus politus (Küster 1849) (Coleoptera: Hydrophilidae)en diferentes condiciones ambientales

La información sobre la tolerancia fisiológica de las especies es esencial para preveer sus respuestas al cambio climático, especialmente en especies de distribución restringida o que habitan ambientes extremos como las aguas salinas continentales. En estos ecosistemas se prevé un aumento de temperatura y salinidad como consecuencia del cambio climático, y ambos factores influyen en la tolerancia térmica de insectos acuáticos. El objetivo de este trabajo fue determinar bajo una aproximación experimental los límites térmicos y su sensibilidad frente a distintas condiciones ambientales en una especie de coleóptero acuático, Enochrus politus, común en ríos salinos del sureste de la Península Ibérica. Como límite térmico inferior se determinó el Supercooling, o temperatura previa a la congelación, y como límite superior se consideró el Heat coma, o punto de parálisis anterior a la muerte, combinando un método dinámico y termografía infrarroja, previa aclimatación de los ejemplares a diferentes condiciones de temperatura y salinidad. Los resultados mostraron que $\mathrm{E}$. politus tiene un amplio rango de tolerancia térmica $\left(-10.38 \pm 0.32{ }^{\circ} \mathrm{C}\right.$ y $\left.57.37 \pm 0.19^{\circ} \mathrm{C}\right)$, siendo mayor en individuos aclimatados a $20^{\circ} \mathrm{C}$ y $12 \mathrm{~g} / \mathrm{L}$, condiciones similares a las de los hábitats donde frecuentemente vive la especie. A bajas temperaturas y salinidad, su rango de tolerancia disminuyó. Tanto la temperatura como la salinidad tuvieron un efecto significativo en ambos límites térmicos. Salinidades elevadas provocaron una disminución de la tolerancia al calor e incrementaron la tolerancia al frío. El límite térmico inferior de la especie mostró mayor plasticidad que el superior. Debido a su amplio rango térmico en comparación 
con otros insectos, esta especie sería potencialmente capaz de hacer frente a un incremento de temperatura, aunque la salinización de su hábitat podría reducir su tolerancia a altas temperaturas.

Palabras clave: Ramblas salinas, Coleoptera, límites térmicos, plasticidad fenotípica, Supercooling, Heat coma.

\section{INTRODUCTION}

The Mediterranean basin has a wide diversity of aquatic inland ecosystems. Among these ecosystems, saline streams ecosystems are considered especially singular, due to their variable and extreme environmental conditions, their halotolerant/halophilic biota and the high number of endemic species that they sustain (Millán et al., 2011). In these ecosystems, high levels of salinity and temperature are frequent; therefore, only a limited number of organisms with specialized adaptations have been able to colonize them. Among these, the insect orders Diptera, Coleoptera and Hemiptera are the most representative among the macroinvertebrate community in saline streams, both in species richness and abundance (Millán et al., 2011).

Although inland saline water ecosystems are globally distributed in arid lands, they are rare in a European context. Despite their high conservation interest, these systems are globally threatened by human pressures, which induce changes in the natural hydrology and salinity levels with a corresponding loss of biodiversity, affecting halophilic biota (Velasco et al., 2006). In addition, climatic models predict an increase in temperature and a decrease in rainfall in Mediterranean regions (IPCC, 2013), with the consequent reduction in available aquatic habitats and an increase in their salinity levels (Sánchez-Fernández et al., 2013). In this context of increasing stress, some traits, such as thermal and salinity tolerances, together with the dispersal ability, determine the species' capacity to persist in their current localities or escape to more suitable habitats (Arribas et al., 2012a; b).

Thermal physiology received a great deal of empirical and theoretical investigations (Angilletta, 2009), given its informative potential to understand the diversity of the physiological adap- tations of organisms (Lutterschmidt \& Hutchison, 1997), the abundance and geographical distribution of species and its variation (Chown \& Terblanche, 2006; Terblanche et al., 2011). Furthermore, it provides insights into the conditions that are limiting for life over the course of its evolution (Pörtner, 2002; Boussau et al., 2008). Growing concerns about the biodiversity impacts of global environmental change stimulated research on the various factors that influence the thermal limits of species and their plasticity (Terblanche et al., 2011, Hofmann \& Todgham, 2010).

Thermal tolerance has two components 1) an intrinsic or genetic component and 2) an acquired component or dependent of acclimation (in the laboratory) or acclimatization (in the field) conditions. Both of the components are good examples of phenotypic plasticity, which reflects the malleability of the organism in response to the environmental conditions experienced (Chown \& Nicolson, 2004). In general, it has been assumed that acclimation is advantageous when organisms are exposed to similar conditions to those at which they were acclimated (Beneficial Acclimation Hypothesis-BAH, Leroi et al., 1994). However, this hypothesis has been questioned because the acclimation or acclimatization also has a high physiological cost (Hoffmann, 1995) and therefore, does not necessarily provide an organism with a performance advantage (e.g., Gilchrist \& Huey, 2001; Stillwell \& Fox, 2005; Deere \& Chown, 2006). Woods \& Harrison (2002) argued that exposure to suboptimal temperatures may decrease survival in all environments (Detrimental Acclimation Hypothesis-DAH). As a consequence, explicit tests for beneficial or deleterious effects should always be undertaken when studying acclimation responses (Marais \& Chown, 2008). Stillman (2003) proposed that those species that have evolved grea- 
ter absolute temperature tolerances have done it at the expense of their ability to acclimatize. However, Calosi et al. (2010) showed that there is a positive relationship between higher temperature tolerance and acclimation capacity in freshwater beetles of the genus Deronectes (F. Dytiscidae). On the other hand, some studies suggest that acclimation capacity seems to be higher in animals living in moderately variable environments and limited in animals in very stable (e.g., Hoffmann \& Harshman, 2000) or highly variable environments (e.g., Sanders et al., 1991; Hofmann \& Somero, 1995).

In aquatic ecosystems, other environmental factors, such as salinity, play an important role and may act additively, synergistically or antagonistically with temperature (Spicer \& Gaston, 1999; Gaston, 2003). Therefore, the thermal tolerance of the organisms may be influenced by other characteristics of the environment, such as osmotic stress (Chown \& Nicolson, 2004). Previous studies show that despite the wide thermal tolerance of some aquatic saline beetle species, acclimation conditions (temperature, salinity and their interaction) may have a significant influence on their thermal limits (Sánchez-Fernández et al., 2010; Arribas et al., 2012b). In this context, research on the thermal tolerance of saline species and acclimation capacity is an issue of great interest to understanding the processes of adaptation to climate change (Terblanche et al., 2011).

The main goal of this study was to experimentally determine the thermal tolerance of the saline beetle species Enochrus politus (Küster 1849) and its plasticity under different acclimation conditions of temperature and salinity. E. politus is a euryhaline species, living in running saline waters and with a circum-Mediterranean range distribution (Millán et al., 2014). Based on the theoretical and empirical background, we predicted that 1) E. politus would present a wide thermal tolerance like other species of the genus; 2) $E$. politus acclimation at high temperatures would increase heat tolerance; 3) E. politus acclimation at low temperatures would increase tolerance to cold; and 4) E. politus acclimation at elevated salinities would increase tolerance to heat and cold. We also predicted that the species would possess a low acclimation capacity, due to the extreme and variable environmental conditions in which they live.

\section{METHODS}

Adults of E. politus were collected from Chícamo stream, a saline and intermittent tributary of the Segura River, located in southeast Spain (30S 670 522 E- $4231172 \mathrm{~N}$ ), in the most arid area of the province of Murcia (Spain). The climate is characterised by a mean annual precipitation below $300 \mathrm{~mm}$ and a mean annual temperature of $18^{\circ} \mathrm{C}$. Annual and interannual variations in rainfall can lead to high discharge variability, with extreme conditions of flooding and drying. The highest flows normally occur in early autumn, followed by a second peak in spring. Chícamo stream is characterized by wide annual, seasonal and diel variabilities in environmental conditions (Vidal-Abarca et al., 2001, 2002). The salinity ranges from $4 \mathrm{~g} / \mathrm{L}$ to $18.3 \mathrm{~g} / \mathrm{L}$, and the temperature ranges seasonally from $7{ }^{\circ} \mathrm{C}$ to $34^{\circ} \mathrm{C}$, with daily variations of up to $18^{\circ} \mathrm{C}$. Basin lithology is dominated by highly impermeable materials (sedimentary marls).The natural cover of the watershed is open Mediterranean scrub, although much is dedicated to agriculture.

\section{Laboratory works}

The specimens were maintained in the laboratory for one day at $20^{\circ} \mathrm{C}$ in $5 \mathrm{~L}$ aquaria containing water and substrate from the collection site to simulate natural conditions. Groups of 50-60 specimens were later acclimated at different combinations of temperature $\left(15^{\circ} \mathrm{C}, 20^{\circ} \mathrm{C}\right.$ and $\left.25^{\circ} \mathrm{C}\right)$ and salinity $(1 \mathrm{~g} / \mathrm{L}, 12 \mathrm{~g} / \mathrm{L}, 35 \mathrm{~g} / \mathrm{L}$ and $60 \mathrm{~g} / \mathrm{L}$ ) in $2 \mathrm{~L}$ aquaria for 7 days under a $12 \mathrm{~h}$ light:12 $\mathrm{h}$ dark cycle in a climatic chamber (Sanyo MLR-351). The chosen temperatures and salinities were representative of the habitat range where the species is present. Saline solutions were prepared by dissolving an appropriate quantity of marine salt (Ocean Fish, Prodac) in distilled water. Organisms were fed with aquatic macrophytes (Cladophora fracta and Enteromor- 
pha intestinalis) ad libitum, but no food was provided $48 \mathrm{~h}$ prior to the determination of thermal limits.

Among the number of potential end-points that exist for both tolerance to heat and cold (Chown \& Nicolson, 2004), here the Heat coma point $(H C)$ or point of paralysis prior to death was considered the upper thermal limit, and the Supercooling point $(S C P)$ or point before the freezing temperature was the lower thermal limit.

Following the acclimation period, individuals from each of the 12 combined treatments were randomly assigned to two equal subgroups $(N=20)$; one was used to measure $H C$ and the other to determine SCP. Specimens were washed with distilled water and dried on absorbent paper, and then placed downside up on a clean, dry rectangular piece of pottery using nontoxic glue (ErichKrause $\mathbb{R}$ ). This procedure ensured that individuals were immobile during the trial.

Thermal limits trials were carried out in air, employing a dynamic method using a ramping rate of $\pm 1{ }^{\circ} \mathrm{C} \min ^{-1}$ (Chown \& Nicolson, 2004) in a controlled-temperature chamber (BINDER MK53, BINDER GmbH, Tuttlingen, Germany) and infrared thermography. The ramping program started at the temperature at which individuals of a given subgroup had been acclimated, until the end points $\left(70^{\circ} \mathrm{C}\right.$ for $\mathrm{HC}$ and $-30{ }^{\circ} \mathrm{C}$ for $S C P$ ) that exceeded the thermal limits in other similar species of water beetles (SánchezFernández et al., 2012). A thermographic camera (FLIR SC305) was coupled to the climatic chamber, and thermal images of each individual during the trial were analysed with the software ThermaCAM Researcher Professional 2.10. A video camera (Sony DCR-DVD110E. Sony Co., Tokyo, Japan) was also used to record the movement of individuals during the experiments. $H C$ was estimated using both video and thermal images. From the video images, the moment at which the movement of legs, antennae and palps ceased was determined, and the body surface temperature at that moment was obtained from infrared thermal images. Such cessation of movement was preceded by spasmodic movements of legs, antennae and palps. The $S C P$ of each individual
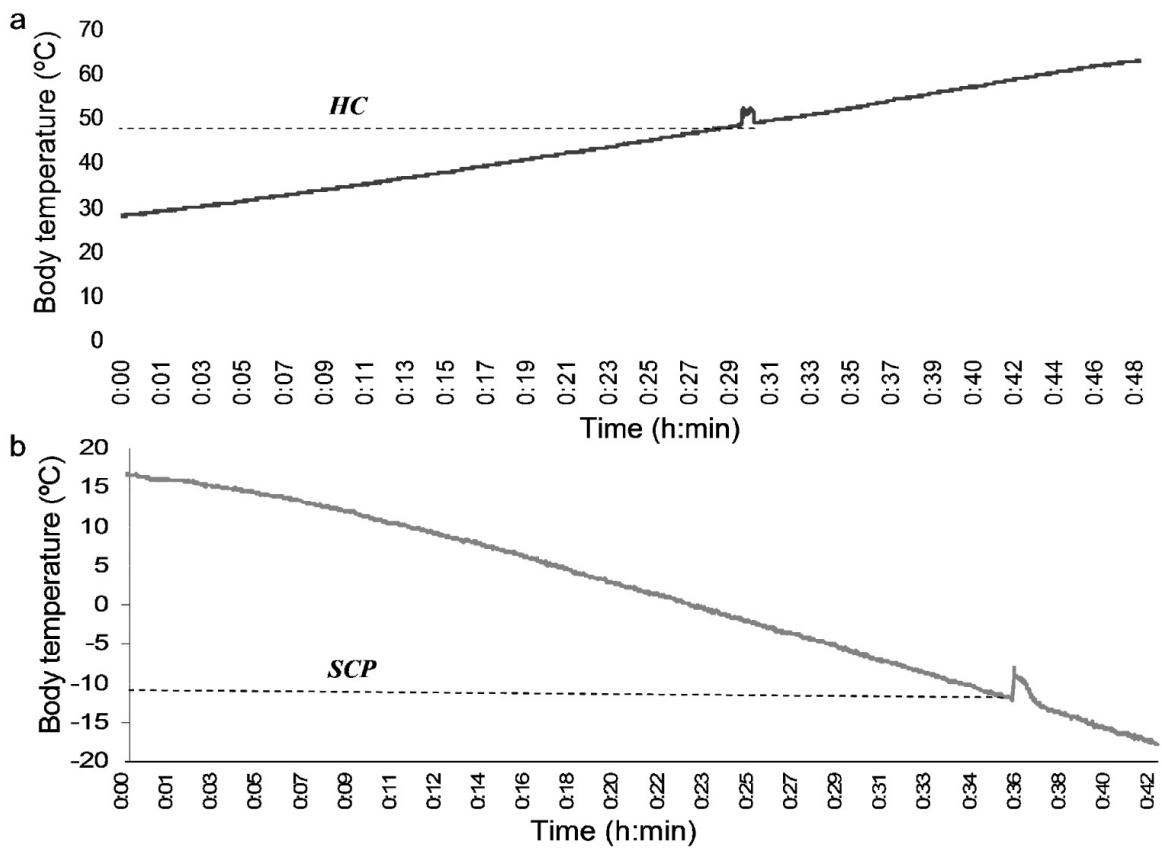

Figure 1. Variation in body temperature of an individual during a) the Heat coma trial and b) the Supercooling trial. Variación de la temperatura corporal de un individuo durante los experimentos a) Heat coma $y b$ ) Supercooling. 
was easily identified because individuals experienced a sudden rise in body temperature due to an exothermic reaction caused by the freezing of the animal's body fluids (Wilson et al., 2003). All of the specimens were sexed by examining their genitalia.

\section{Data analysis}

An analysis of variance (ANOVA) was used with untransformed data to investigate the effects of salinity and temperature of acclimation and their interactions on both thermal limits. Previous analyses showed no differences between sexes; therefore, sex was excluded from the subsequent analyses. The data met the assumptions of normality and homogeneity of variances. A post-hoc Bonferroni analysis was implemented to identify significant differences in the response variables among acclimation treatments (Underwood, 1997; Rutherford, 2001). The acclimation capacity in thermal limits was estimated as the magnitude of the variation (increment or decline) in $H C$ and $S C P$ in response to the increase of the acclimation temperature (Calosi et al., 2008). The relationship between both thermal limits was analysed by Pearson correlation. All of the statistical analyses were conducted using SPSS, version 19.0.

\section{RESULTS}

\section{Heat coma $(\mathrm{HC})$}

During the heat trials, the movement of legs, antennae and palps of organisms increased with increasing temperature. When body temperature reached approximately $48^{\circ} \mathrm{C}$, spasmodic movements alternated with short periods of immobility, until the total cessation of movements. $H C$ was preceded by accelerated movements of legs and an abrupt increase of body temperature, as a result of the intense heat generated (Fig. 1a).

The highest mean value of $H C\left(54.24 \pm 0.29^{\circ} \mathrm{C}\right)$ was reached in those individuals acclimated at $25^{\circ} \mathrm{C}$ and $1 \mathrm{~g} / \mathrm{L}$, and the lowest mean value of $\mathrm{HC}$ $\left(52 \pm 0.26^{\circ} \mathrm{C}\right)$ was reached at $20^{\circ} \mathrm{C}$ and $60 \mathrm{~g} / \mathrm{L}$ (Fig. 2a). Significant differences in $H C$ were found among acclimation temperatures, although the $p$ value was close to the significance level (Table 1). Heat tolerance was lower in the individuals acclimated at $20^{\circ} \mathrm{C}$ than in those acclimated at $10^{\circ} \mathrm{C}$ and $25^{\circ} \mathrm{C}$ (Fig. 2a). Regarding

Table 1. ANOVA results for Heat coma and Supercooling. Resultado del ANOVA para el Heat coma y Supercooling.

\begin{tabular}{|c|c|c|c|c|c|c|}
\hline & Origin & $\sum$ square type III & df & Mean square & $\mathrm{F}$ & $p$ \\
\hline \multirow{8}{*}{ Heat coma } & Corrected model & 97.92 & 11 & 8.90 & 6.45 & $<0.001$ \\
\hline & Intercept & 697338.28 & 1 & 697338.28 & 504830.29 & $<0.001$ \\
\hline & Temperature & 8.99 & 2 & 4.50 & 3.26 & 0.040 \\
\hline & Salinity & 70.74 & 3 & 23.58 & 17.07 & $<0.001$ \\
\hline & Temperature * Salinity & 14.55 & 6 & 2.42 & 1.76 & 0.109 \\
\hline & Error & 341.19 & 247 & 1.38 & & \\
\hline & Total & 737224.78 & 259 & & & \\
\hline & Total corrected & 439.11 & 258 & & $\mathrm{R}^{2}=0.34\left(\mathrm{R}^{2}\right.$ corrected $\left.=0.31\right)$ & \\
\hline \multirow{8}{*}{ Supercooling } & Corrected model & 271.93 & 11 & 24.72 & 10.93 & $<0.001$ \\
\hline & Intercept & 25919.51 & 1 & 25919.51 & 11455.39 & $<0.001$ \\
\hline & Temperature & 148.25 & 2 & 74.12 & 32.76 & $<0.001$ \\
\hline & Salinity & 47.78 & 3 & 15.92 & 7.04 & $<0.001$ \\
\hline & Temperature * Salinity & 52.09 & 6 & 8.68 & 3.84 & 0.001 \\
\hline & Error & 538.51 & 238 & 2.26 & & \\
\hline & Total & 28082.61 & 250 & & & \\
\hline & Total corrected & 810.44 & 249 & & $\mathrm{R}^{2}=0.22\left(\mathrm{R}^{2}\right.$ corrected $\left.=0.19\right)$ & \\
\hline
\end{tabular}


salinity, there were no significant differences between acclimation treatments of $1 \mathrm{~g} / \mathrm{L}$ and $12 \mathrm{~g} / \mathrm{L}$ and between $35 \mathrm{~g} / \mathrm{L}$ and $60 \mathrm{~g} / \mathrm{L}$; however, there were differences between both groups, as the individuals acclimated at lower salinities had a greater heat tolerance (Fig. 2a). The interaction of salinity and temperature of acclimation was not significant (Table 1).

\section{Supercooling (SCP)}

During cold ramping experiments, individuals vigorously beat their legs in temperatures ranging between $7^{\circ} \mathrm{C}$ and $4{ }^{\circ} \mathrm{C}$. From there, the movements decreased, ceasing at temperatures between $-4{ }^{\circ} \mathrm{C}$ to $-7{ }^{\circ} \mathrm{C}$. Body temperature gradually decreased until the $S C P$; at this point, a sudden increase of $0.7-2.5^{\circ} \mathrm{C}$ in body temperature was registered (Fig. 1b).

The lowest mean SCP $\left(-11.61 \pm 0.35^{\circ} \mathrm{C}\right)$, i.e., the highest cold tolerance, was observed in individuals acclimated at $20^{\circ} \mathrm{C}$ and $12 \mathrm{~g} / \mathrm{L}$, and the highest mean $S C P$ (lowest cold tolerance, $-7.86 \pm 0.34^{\circ} \mathrm{C}$ ) was observed at $15^{\circ} \mathrm{C}$ and $1 \mathrm{~g} / \mathrm{L}$ (Fig. 2b). SCP was significantly influenced by temperature, salinity and their interaction (Table 1).

Regarding temperature, the maximum mean
SCP was measured in individuals acclimated at $15^{\circ} \mathrm{C}\left(-9.22 \pm 0.19^{\circ} \mathrm{C}\right)$, and no significant differences were found between the $20^{\circ} \mathrm{C}$ and $25^{\circ} \mathrm{C}$ treatments. Individuals acclimated at $1 \mathrm{~g} / \mathrm{L}$ were less cold tolerant $\left(-9.53 \pm 0.27^{\circ} \mathrm{C}\right)$ than those acclimated at higher salinities, although no significant differences were detected between the $12 \mathrm{~g} / \mathrm{L}, 35 \mathrm{~g} / \mathrm{L}$ and $60 \mathrm{~g} / \mathrm{L}$ treatments (Fig. 2b).

The effect of the interaction between both factors was observed only at the lowest temperature tested $\left(15^{\circ} \mathrm{C}\right)$, where cold tolerance was higher as the acclimation salinity increased (Fig. 2b).

\section{Thermal range and plasticity of thermal limits}

The upper and lower thermal limits were not significantly correlated (Pearson $r=0.208$, $p=0.496)$. The highest tolerance range for this species was found in individuals acclimated at $20^{\circ} \mathrm{C}$ and $12 \mathrm{~g} / \mathrm{L}$, whereas the lowest tolerance range was found at $15^{\circ} \mathrm{C}$ and $1 \mathrm{~g} / \mathrm{L}$ acclimation conditions (Table 2).

The mean overall acclimation capacity in response to temperature (i.e., the variation of thermal limits among the acclimation treatments) was $-1.9^{\circ} \mathrm{C}$ for $S C P$ and $0.16^{\circ} \mathrm{C}$ for $H C$. The

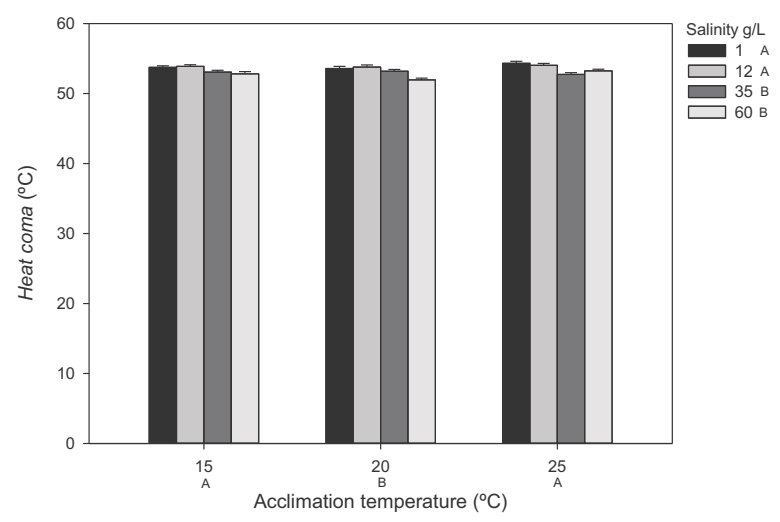

(a)

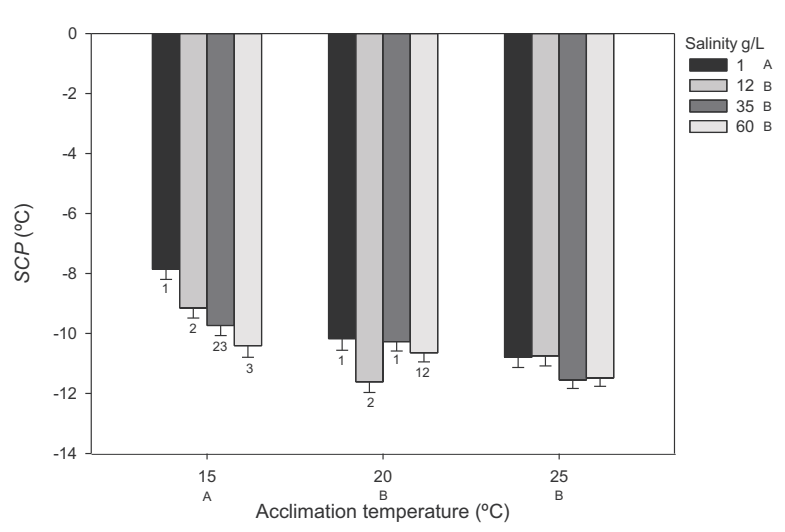

(b)

Figure 2. a) The mean \pm SE Heat coma and b) Supercooling points of E. politus acclimated to different temperatures and salinities. Significantly different means $(p \leq 0.05)$ measured at different acclimation temperatures and salinities are indicated by different letters in the temperature axis and salinity legend, respectively. Significantly different means measured at different salinities within the same temperature treatment are indicated by different numbers below the bars. a) Media \pm ES para el Heat coma $y$ b) Supercooling de Enochrus politus aclimatado a diferentes tratamientos de temperatura y salinidad. Las diferencias significativas para las temperaturas de aclimatación están indicadas con letras en el eje y para las salinidades están en la leyenda. Diferencias entre salinidades para cada tratamiento de temperatura están indicadas con números bajo las barras. 
plasticity of $S C P$ to increasing temperatures differed at the different acclimation salinities. At freshwater and low salinities $(1 \mathrm{~g} / \mathrm{L}$ and $12 \mathrm{~g} / \mathrm{L})$, the plasticity of $S C P$ was higher from $15^{\circ} \mathrm{C}$ to $20^{\circ} \mathrm{C}$ than from $20^{\circ} \mathrm{C}$ to $25^{\circ} \mathrm{C}$ (Table 2). However, at higher salinities $(35 \mathrm{~g} / \mathrm{L}$ and $60 \mathrm{~g} / \mathrm{L})$, the acclimation capacity of $S C P$ was higher from $20^{\circ} \mathrm{C}$ to $25^{\circ} \mathrm{C}$. The greatest changes in $H C$ occurred when the species was acclimated at $60 \mathrm{~g} / \mathrm{L}$, resulting in a decline of $0.79^{\circ} \mathrm{C}$ when changing from $15^{\circ} \mathrm{C}$ to $20^{\circ} \mathrm{C}$ and an increase of $1.25^{\circ} \mathrm{C}$ from $20^{\circ} \mathrm{C}$ to $25^{\circ} \mathrm{C}$ (Table 2).

\section{DISCUSSION}

E. politus can be considered a thermal generalist species, given its wide temperature tolerance range $\left(-10.38 \pm 0.32^{\circ} \mathrm{C}\right.$ and $\left.57.37 \pm 0.19^{\circ} \mathrm{C}\right)$, similar to other species of the genus, such as E. bicolor (Fabricius) $\left(-11.57^{\circ} \mathrm{C}\right.$ and $\left.52.45^{\circ} \mathrm{C}\right)$ and $E$. jesusarribasi Arribas \& Millán (named as E. falcarius IP in Arribas et al., 2012b) $\left(-11.57^{\circ} \mathrm{C}\right.$ and $53.07{ }^{\circ} \mathrm{C}$ ), although in these species, the lower thermal limits were measured as lethal points and not as SCP (Arribas et al., 2012b). The upper thermal limits reported here were likely overestimated, since the ramping rates used in dy- namic experiments $\left( \pm 1^{\circ} \mathrm{C} \min ^{-1}\right)$ do not represent realistic thermal changes experienced by organisms in nature, although ramping assays are thought to be more relevant to natural conditions than other approaches (Terblanche et al., 2011). However, the high upper thermal limit of E. politus, which was consistent with those of its congener species $\left(>50^{\circ} \mathrm{C}\right)$, exceeded the temperature tolerated by most insects. The average upper thermal limit for insects is $41.6^{\circ} \mathrm{C}$, and temperatures above $47.8^{\circ} \mathrm{C}$ are thought to be tolerated only temporarily by animals (Araújo et al., 2013) or by those from extreme environments, such as desert species (e.g., Wehner et al., 1992). Preliminary trials at a constant temperature showed that E. politus can tolerate up to $46^{\circ} \mathrm{C}$ for $6 \mathrm{~h}$ (unpublished data).

This species also showed a higher thermal tolerance than other beetle saline species from different genera and families occupying similar habitats, such as Nebrioporus (Dytiscidae), with ranges from $-5.20{ }^{\circ} \mathrm{C}$ to $45.24{ }^{\circ} \mathrm{C}$ in $N$. baeticus (Schaum) and $-6.07^{\circ} \mathrm{C}$ to $45.42^{\circ} \mathrm{C}$ in $N$. ceresyi (Aubé) (Sánchez-Fernández et al., 2010), and Octhebius (F. Hydraenidae), with ranges from -13.79 to $47.98^{\circ} \mathrm{C}$ in $O$. glaber Montes \& Soler and -12.57 to $48.61{ }^{\circ} \mathrm{C}$ in $O$. notabilis Rosenhauer (Arribas et al., 2009). Tolerance to heat is

Table 2. Thermal range and plasticity of thermal limits. Rango térmico y plasticidad de los límites térmicos.

\begin{tabular}{|c|c|c|c|c|c|c|}
\hline \multicolumn{2}{|c|}{ Acclimation conditions } & \multirow[b]{2}{*}{ SCP } & \multirow[b]{2}{*}{$\triangle \mathrm{SCP}$} & \multirow[b]{2}{*}{ Heat coma } & \multirow[b]{2}{*}{$\Delta H C$} & \multirow[b]{2}{*}{ Thermal range } \\
\hline Temperature $\left({ }^{\circ} \mathrm{C}\right)$ & Salinity $(\mathrm{g} / \mathrm{L})$ & & & & & \\
\hline 15 & 1 & -7.86 & & 53.68 & & 61.54 \\
\hline 20 & 1 & -10.17 & -2.31 & 53.72 & 0.04 & 63.89 \\
\hline 25 & 1 & -10.79 & -0.62 & 54.29 & 0.57 & 65.08 \\
\hline 15 & 12 & -9.15 & & 53.92 & & 63.07 \\
\hline 20 & 12 & -11.69 & -2.54 & 53.78 & -0.14 & 65.47 \\
\hline 25 & 12 & -10.75 & 0.94 & 53.98 & 0.2 & 64.72 \\
\hline 15 & 35 & -9.66 & & 53.26 & & 62.92 \\
\hline 20 & 35 & -10.37 & -0.71 & 52.99 & -0.27 & 63.36 \\
\hline 25 & 35 & -11.52 & -1.15 & 52.8 & -0.19 & 64.33 \\
\hline 15 & 60 & -10.33 & & 52.78 & & 63.11 \\
\hline 20 & 60 & -10.7 & -0.37 & 51.99 & -0.79 & 62.69 \\
\hline 25 & 60 & -11.55 & -0.85 & 53.24 & 1.25 & 64.79 \\
\hline $\begin{array}{l}\text { Mean thermal limits } \\
\text { and acclimation capacity }\end{array}$ & & -10.61 & -1.9 & 53.34 & 0.16 & 63.95 \\
\hline
\end{tabular}


largely conserved across lineages (Araújo et al., 2013). Thus, the wide thermal tolerance in the Enochrus species could be a conservative character of the genus, and the thermal differences with cohabiting species from different genera probably reflect the thermal heterogeneity that organisms with different adaptations to the aquatic environment experience at a microhabitat scale. In this sense, although Enochrus species are known as truly water beetles (Jäch \& Balke, 2008), they usually occupy the shorelines of water bodies, where changing and more extreme temperatures are frequent when compared with those experienced by benthos and water column species.

The thermal tolerance of the species was influenced by both salinity and temperature, as previous studies on saline insect species found (Sánchez-Fernández et al., 2010; Arribas et al., 2009, 2012b; Coccia et al., 2013). Concerning E. poli$t u s$, its thermal range was maximized in middle acclimation conditions of temperature $\left(20^{\circ} \mathrm{C}\right)$ and salinity $(12 \mathrm{~g} / \mathrm{L})$, similar to the mean conditions in the species' habitat.

\section{Heat tolerance}

The acclimation temperature and salinity had significant effects on the heat tolerance in E. politus. However, contrary to the expected result, there was no clear pattern of increasing $H C$ with the acclimation temperature ( $2^{\text {nd }}$ prediction rejected), and the heat tolerance decreased with the salinity of acclimation ( $4^{\text {th }}$ prediction rejected). However, in the sister species E. jesusarribasi, the mean in the upper thermal limit (UTL) increased with both temperature and salinity of acclimation (Arribas et al., 2012b), and similar results were found in Nebrioporus species (SánchezFérnandez et al., 2010) and other aquatic insects, such as the corixid Trichocorixa verticalis (Fieber) (Coccia et al., 2013). The mentioned beetle species showed greater salinity tolerance than E. politus, both from experimental and field data (e.g., Céspedes et al., 2013), as the former were more efficient osmoregulators (Pallarés et $a l ., 2015)$. This could explain why the observed negative effect of high salinities (i.e., above $35 \mathrm{~g} / \mathrm{L}$ ) on thermoregulatory mechanisms in $E$. politus was not found in other saline species under the same range of acclimation salinities.

The combination of high temperature and salinity caused a decrease in the upper thermal limit in E. politus, which suggested that a tradeoff between tolerances to both stressors may exist (Angilletta et al., 2003). The mechanisms underlying tolerance to osmotic and thermal stress are highly energetically costly, and complex interactions might arise when organisms are exposed to sublethal levels of both stressors.

Osmoregulation mechanisms may breakdown under high temperatures (e.g., Segal \& Burbanck, 1963; Punzo, 1989). By contrast, the osmoregulatory effort in hyperosmotic media may result in decreased energy derived for thermoregulatory mechanisms, such as the production of heat shock proteins (Hsp). Under conditions of high heat and salinity stress, the temperature from which Hsp production is induced may decrease, reducing the upper thermal limit (Tomanek et $a l ., 2011)$. The role of Hsp in heat tolerance was widely documented (e.g., see Haranda et al., 2011), especially in model organisms, such as Drosophila spp. (e.g., Welte et al., 1993, Feder et al., 1996, Bettencourt et al., 2008, Krebs \& Feder, 1998). Aquatic saline species also constitute a good model for the study of Hsp under multiple stressors, since these species are adapted to naturally stressful conditions, and some of them are able to tolerate extreme temperatures, as shown by our study and previous work (Arribas et al., 2009, 2012b; Sánchez-Férnandez et al., 2010).

\section{Freezing tolerance}

E. politus showed a higher freezing tolerance (lower SCP values) when acclimated at higher $\left(20^{\circ} \mathrm{C}\right.$ and $\left.25^{\circ} \mathrm{C}\right)$ rather than lower temperature $\left(15^{\circ} \mathrm{C}\right)$, contrary to our $3^{\text {rd }}$ prediction and to the pattern found in E. jesusarribasi (Arribas et al., 2012b). However, regarding salinity, the studied species increased its freezing tolerance when subjected to higher salinity acclimation conditions, as was expected (4 $4^{\text {th }}$ prediction). Similar salinity acclimation effects over lower lethal thermal limits were also found by SánchezFernández et al. (2010) in two dytiscid saline 
beetle species (Nebrioporus ceresyi and N. baeticus) and by Coccia et al. (2013) in some corixid species. These positive effects of water salinity on freezing tolerance can be related to the organism's osmotic regulation ability to maintain ion homeostasis. A higher SCP (lower freezing tolerance) in freshwater (hypoosmotic conditions) is probably due to some dilution of the internal medium of the organism, i.e., a low osmolality of the haemolymph, which increases the temperature of the freezing point (Bradley, 2009). On the contrary, a higher haemolymph osmotic concentration in more saline media (Pallarés et al., 2015) would increase the freezing point of internal fluids.

\section{Acclimation capacity}

As expected, E. politus presented a limited ability for thermal acclimation of the upper thermal limit, as other congeneric species (Arribas et al., 2012b), but some degree of phenotypic plasticity of the lower thermal limit was found. These results agreed with some studies that investigated the effects of acclimation temperature on the thermal limits conducted at rates $\geq 0.25^{\circ} \mathrm{C}$, which found that the maximum thermal limit was less responsive to treatments than the minimum thermal limit (e.g., Klok \& Chown, 2003; Terblanche et al., 2006). However, as the acclimation capacity depends on the rates of change of the temperature used in the experimental determination of the thermal limits (Chown et al., 2009), making comparisons is difficult.

Some studies suggest that acclimation capacity seems to be higher in animals living in moderately variable environments and limited in animals of very stable (e.g., Hoffmann \& Harshman, 2000) or highly variable environments (e.g., Sanders et al., 1991; Hofmann \& Somero, 1995). Some examples of the absence of thermal acclimation in the upper thermal limit can be found in insects associated with extreme environments, such as Stratiomys japonica Wulp (Garbuz et al., 2008) and larvae of the Antarctic fly Belgica antarctica Jacobs (Rinehart et al., 2006), but also in the freshwater dytiscid species (Calosi et al., 2008).
Species whose habitat and climatic preferences are close to their upper thermal limit probably cannot develop physiological temperature increased tolerances, so they will be more sensitive to climate change (Tomanek, 2008; Araújo et al., 2013). In the case of E. politus, its high heat tolerance $\left(57.37 \pm 0.19^{\circ} \mathrm{C}\right)$ is far from the maximum water temperature reached in their habitats $\left(35^{\circ} \mathrm{C}\right)$ and, despite the species' low acclimation capacity, it might be able to survive the temperature rise of several degrees expected under climate change scenarios in the mediumand long-term (IPCC, 2013). However, according to our results, the combination of increased temperature and salinity and the persistence of more extreme conditions in inland water bodies could decrease the species' thermal range.

\section{ACKNOWLEDGEMENTS}

We would like to thank the members of the Aquatic Ecology research group (University of Murcia, Spain) for field and laboratory assistance. This study was supported by I+D project CGL201348950-C2-2-P (J.V. and A.M.) co-financed with Feder funds.

\section{REFERENCES}

ANGILLETTA, M. J. 2009. Thermal Adaptation: A Theoretical and Empirical Synthesis. Oxford University Press. New York. USA

ANGILLETTA, M. J., R. S. WILSON, C. A. NAVAS $\&$ R. S. JAMES. 2003. Trade-off and the evolution of thermal reaction norms. Trends in Ecology and Evolution, 18: 234-240.

ARAÚJO, M. B., F. FERRI-YÁÑEZ, F. BOZINOVIC, P. A. MARQUET, F. VALLADARES \& S. L. CHOWN 2013. Heat freeze niche evolution. Ecology Letters, 16: 1206-1219.

ARRIBAS, P., J. VELASCO, P. ABELLÁN, D. SÁNCHEZ-FERNÁNDEZ, P. CALOSI, D. T. BILTON \& A. MILLÁN. 2009. Dispersal responses and tolerance to temperature and salinity in two Hydraenidae beetles from hypersaline inland waters. Comparative biochemistry and physiology a-molecular \& integrative physiology, 153A: 171-172. 
ARRIBAS, P., P. ABELlÁN, J. VELASCO, D. T. BILTON, A. MILLÁN \& D. SÁNCHEZ-FERNÁNDEZ. 2012a. Evaluating drivers of vulnerability to climate change: a guide for insect conservation strategies. Global Change Biology, 18(7): 2135-2146.

ARRIBAS, P., J. VELASCO, P. ABELLÁN, D. SÁNCHEZ-FERNANDEZ, C. ANDÚJAR, P. CALOSI, A. MILLÁN, I. RIBERA \& D. T. BILTON. 2012b. Dispersal ability rather than ecological tolerance drives differences in range size between lentic and lotic water beetles (Coleoptera: Hydrophilidae). Journal of Biogeography, 39(5): 884894.

BETTENCOURT, B. R., C. C. HOGAN, M. NIMALI \& B. W. DROHAN. 2008. Inducible and constitutive heat shock gene expression responds to modification of Hsp70 copy number in Drosophila melanogaster but does not compensate for loss of thermotolerance in Hsp70 null flies. BMC Biology, 6: 5-15.

BOUSSAU, B., S. BLANQUART, A. NECSULEA, N. LARTILLOT \& M. GOUY. 2008. Parallel adaptations to high temperatures in the Archaeaneon. Nature, 456: 942-945.

BRADLEY, T. J. 2009. Animal osmoregulation. Oxford Animal biology Series. Oxford University Press. Oxford. UK.

CALOSI, P., D. T. BILTON, J. I. SPICER, \& A. ATFIELD. 2008. Thermal tolerance and geographic range size in the Agabus brunneus group of European diving beetles (Coleoptera: Dytiscidae). Journal of Biogeography, 35: 295-305.

CALOSI, P., D. T. BILTON, J. I. SPICER, S. C. VOLTIER \& A. ATFIELD. 2010. What determines a species' geographical range? Thermal biology and latitudinal range size relationships in European diving beetles (Coleoptera: Dytiscidae). Journal of Animal Ecology, 79: 194-204.

CÉSPEDES, V., S. PALLARÉS, P. ARRIBAS, A. MILLÁN \& J. VELASCO. 2013. Water beetle tolerance to salinity and anionic composition and its relationship to habitat occupancy. Journal of Insect Physiology, 59: 1076-1084.

CHOWN, S. L \& S. NICOLSON. 2004. Insect Physiological Ecology. Mechanisms and patterns. Oxford University Press. Oxford. UK.

CHOWN, S. L. \& J. S. TERBLANCHE. 2006. Physiological diversity in insects: ecological and evolutionary contexts. Advances in Insect Physiology, 33: $50-152$.
CHOWN, S. L., K. R. JUMBAM, J. G. SØRENSEN \& J. S. TERBLANCHE. 2009. Phenotypic variance, plasticity and heritability estimates of critical thermal limits depend on methodological context. Functional Ecology, 23: 133-140.

COCCIA, C., P. CALOSI, L. BOYERO, A. J. GREEN \& D. T. BILTON. 2013. Does Ecophysiology Determine Invasion Success? A Comparison between the Invasive Boatman Trichocorixa verticalis verticalis and the Native Sigara lateralis (Hemiptera, Corixidae) in South-West Spain. PLoS ONE 8(5), doi: 10.1371/annotation/2c817fcd-acf8-49ea-82cb74776a3eeb9b.

DEERE, J. A. \& S. L. CHOWN. 2006. Testing the beneficial acclimation hypothesis and its alternatives for locomotor performance. The American Naturalist, 168: 630-644.

FEDER, M., N. V. CARTAÑO, L. MILOS, R. A. KREBS \& S. L. LINDQUIST. 1996. Effect of engineering Hsp70 copy number on Hsp70 expression and tolerance of ecologically relevant heat shock in larvae and pupae of Drosophila melanogaster. Journal of Experimental Biology, 199: 1837-1844.

GARBUZ,D. G., O. G. ZATSEPINA \& A. A. PRZHIBORO. 2008. Larvae of related Diptera species from thermally contrasting habitats exhibit continuous up-regulation of heat shock proteins and high thermotolerance. Molecular Ecology, 17: 4763-4777.

GASTON, K. J. 2003. The structure and dynamics of geographic ranges. Oxford University Press. Oxford. UK.

GILCHRIST, G. W. \& R. B. HUEY. 2001. Parental and developmental temperature effects on the thermal dependence of fitness in Drosophila melanogaster. Evolution, 55: 209-214.

HARANDA, T., S. TAKENAKA, T. SEKIMOTO, M. NAKAJYO, I. TAKAO \& C. KATAGIRI. 2011. Heat coma as an indicator of resistance to environmental stress and its relationship to ocean dynamics in the sea skaters, Halobates (Heteroptera: Gerridae). Insect Science, 18: 703-711.

HOFFMANN, A. A. 1995. Acclimation: increasing survival at a cost. Trends in Ecology and Evolution, 10: $1-2$.

HOFFMANN, A. A., L. G. HARSHMAN. 2000. Desiccation and starvation resistance in Drosophila: patterns of variation at the species, population and intrapopulation levels. Heredity, 83: 637-43. 
HOFMANN, G. E. \& G. N. SOMERO. 1995. Evidence for protein damage at environmental temperatures: Seasonal changes in levels of ubiquitin conjugates and hsp70 in the intertidal mussel Mytilus trossulus. Journal of Experimental Biology, 198: 1509-1518.

HOFMANN, G. E. \& A. E. TODGHAM. 2010. Living in the now: physiological mechanisms to tolerate a rapidly changing environment. Annual Review of Physiology, 72: 127-145.

IPCC. 2013. Climate Change 2013: The Physical Science Basis. Contribution of Working Group I to the Fifth Assessment Report of the Intergovernmental Panel on Climate Change. T.F. Stocker, D. Qin, G.K. Plattner, M. Tignor, S.K. Allen, J. Boschung, A. Nauels, Y. Xia, V. Bex \& P.M. Midgley (eds.). 1535 pp. Cambridge University Press, Cambridge, UK and New York, USA.

JÄCH, M. A. \& M. BALKE. 2008. Global diversity of water beetles (Coleoptera) in freshwater. Hydrobiologia, 595: 419-442.

KLOK, C. J \& S. L. CHOWN. 2003. Resistance to temperature extremes in sub-Antarctic weevils: interspecific variation, population differentiation and acclimation. Biological Journal of the Linnean Society, 78: 401-414.

KREBS, R. A. \& M. E. FEDER. 1998. Hsp70 and larval thermotolerance in Drosophila melanogater: how much is enough and when is more too much? Journal Insect Physiology, 44: 1091-1101.

LEROI, A. M., A. F BENNETT \& R. E. LENSKI. 1994. Temperature acclimation and competitive fitness: An experimental test of the Beneficial Acclimation Hypothesis. Proceedings of National Academy of Sciences, 91: 1917-1921.

LUTTERSCHMIDT, W. I. \& V. H. HUTCHISON. 1997. The critical thermal maximum: data to support the onset of spasms as the definitive end point. Canadian Journal of Zoology, 75: 1553-1560.

MARAIS, E. \& S. L. CHOWN. 2008. Beneficial acclimation and the Bogert effect. Ecology Letters, 11: 1027-1036.

MILLÁN, A., J. VELASCO, C. GUTIÉRREZ-CÁNOVAS, P. ARRIBAS, F. PICAZO, D. SÁNCHEZFERNÁNDEZ \& P. ABELLÁN. 2011. Mediterranean saline streams in southeast Spain: What do we know? Journal of Arid Environments, 75(12): 1352-1359.

MILLÁN, A., D. SÁNCHEZ-FERNÁNDEZ, P. ABELLÁN, F. PICAZO, J. A. CARBONELL, J. M. LOBO \& I. RIBERA. 2014. Atlas de los Coleóp- teros Acuáticos de España Penínsular. MAGRAMA. Madrid. Spain.

PALLARÉS, S., P. ARRIBAS, D. BILTON, A. MILLÁN \& J. VELASCO. 2015. The comparative osmoregulatory ability of two water beetle genera whose species span the fresh-hypersaline gradient in inland waters (Coleoptera: Dytiscidae, Hydrophilidae). PLoS ONE. 10(4): e0124299. doi: 10.1371/journal.pone.0124299

PÖRTNER, H. 2002. Climate variations and the physiological basis of temperature dependent biogeography: systemic to molecular hierarchy of thermal tolerance in animals. Comparative Biochemistry and Physiology, 132A: 739-761.

PUNZO, F. 1989. Comparative temperature and water relations and hemolymph osmoregulation in the desert insects, Taeniopoda eques and Schistocerca vaga (Orthoptera, Acrididae). Comparative Biochemistry and Physiology, 93A (4): 751-755.

RINEHART, J. P., S. A. HAYWARD \& M. A. ELNITSKY. 2006. Continuous up-regulation of heat shock proteins in larvae, but not adults, of a polar insect. Proceedings of the National Academy of Sciences of the United States of America, 103: 14223-14227.

RUTHERFORD, A. 2001. Introducing ANOVA and ANCOVA a GLM approach. SAGE Publications. London. UK.

SÁNCHEZ-FERNÁNDEZ, D., P. CALOSI, A. ATFIELD, P. ARRIBAS, J. VELASCO, J. I. SPICER, A. MILLÁN \& D. T. BILTON. 2010. Reduced salinities compromise the thermal tolerance of hypersaline specialist diving beetles. Physiological Entomology, 35(3): 265-273.

SÁNCHEZ-FERNÁNDEZ, D., P. ARAGÓN, D. T. BILTON \& J. M. LOBO 2012. Assessing the Congruence of Thermal Niche Estimations Derived from Distribution and Physiological Data. A Test Using Diving Beetles. PLoS ONE, 7(10), e48163. doi:10.1371/journal.pone.0048163.

SÁNCHEZ-FERNÁNDEZ, D., P. ABELLÁN, F. PICAZO, A. MILLÁN, I. RIBERA \& J. M. LOBO. 2013. Do protected areas represent species' optimal climatic conditions? Diversity and Distributions, 19: 1407-1417.

SANDERS, B. M., C. HOPE, V. M. PASCOE \& L. S. MARTIN. 1991. Characterization of stress protein response in two species of Collisella limpets with different temperature tolerances. Physiological and Biochemical Zoology, 64: 1471-1489. 
SEGAL, E. \& BURBANCK W. D. 1963. Effects of Salinity and Temperature on Osmoregulation in Two Latitudinally Separated Populations of an Estuarine Isopod, Cyathura polita (Stimpson). Physiological Zoology, 36(3): 250-263.

SPICER, J. I. \& K. J. GASTON, 1999. Physiological diversity and its ecological implications. Blackwell Science. Oxford. UK.

STILLMAN, J. H. 2003. Acclimation capacity underlies susceptibility to climate change. Science, 301: 65.

STILLWELL, R. C. \& C. W. FOX. 2005. Complex patterns of phenotypic plasticity: interactive effects of temperature during rearing and oviposition. Ecology, 86: 924-934.

TERBLANCHE, J., C. J. KLOK, E. S. KRAFSUR \& S. L. CHOWN. 2006. Phenotypic plasticity and geographic variation in thermal tolerance and water loss of the tsetse Glossina pallidipes (Diptera: Glossinidae): implications for distribution modelling. American Journal of Tropical Medicine and Hygiene, 74: 786-794.

TERBLANCHE, J. S., A .A., HOFFMANN, K. A., MITCHELL, L., RAKO, P. C., LE ROUX \& S. L., CHOWN. 2011. Ecologically relevant measures of tolerance to potentially lethal temperatures. Journal of Experimental Biology, 214(22): 3713-3725.

TOMANEK, L. 2008. The importance of physiological limits in determining biogeographical range shifts due to global warming: the heat shock response. Physiological and Biochemical Zoology, 81: 709-717.

TOMANEK, L., M. J. ZUZOW, A. V. IVANINA, E. BENIASH \& I. M. SOKOLOVA. 2011. Proteomic responses to elevated $\mathrm{PcO} 2$ level in eastern oysters, Crassostrea virginica: evidence for oxidative stress. Journal of Experimental Biology, 214: 1836-1844.
UNDERWOOD, A. J. 1997. Experiments in Ecology: Their Logical Design and Interpretation Using Analysis of Variance. Cambridge University Press. Cambridge. U.K.

VELASCO, J., A. MILLÁN, J. HERNÁNDEZ, C. GUTIÉRREZ-CÁNOVAS，D. SÁNCHEZ-FERNÁNDEZ, P. ABELLÁN \& M. RUIZ. 2006. Response of biotic communities to salinity changes in a Mediterranean hypersaline stream. Saline Systems, 12 (2): 1-15.

VIDAL-ABARCA, M. R., M. L. SUÁREZ, C. GUERRERO; J. VELASCO, J. L. MORENO ,A. MILLÁN \& A. PERÁN. 2001. Dynamics of dissolved and particulate organic carbon in a saline and semiarid stream of southeast Spain (Chicamo stream). Hydrobiologia, 455: 71-78.

VIDAL-ABARCA, M. R., M. L. SUÁREZ, R. GÓMEZ, J. L. MORENO \& C. GUERRERO. 2002. Diel variations in physical and chemical parameters in a semi-arid stream in Spain (Chicamo Stream). Verhandlungen des Internationalen Verein Limnologíe, 28: 1111-1115.

WEHNER, R., A. C. MARSH \& S. WEHNER. 1992. Desert ants on a thermal tightrope. Nature, 357: 586-587.

WELTE, M. A., J. M. TETRAULT, R. P. DELLAVALLE, \& S. L. LINDQUIST. 1993. A new method for manipulating transgenes: engineering heat tolerance in a complex, multicellular organism. Current Biology, 3: 842-853.

WILSON, P. W., A. F. HENEGHAN \& A. D. J. HAYMET. 2003. Ice nucleation in nature: supercooling point (SCP) measurements and the role of heterogeneous nucleation. Cryobiology, 46: 88-98.

WOODS, H. A \& J. F. HARRISON. 2002. Interpreting rejections of the beneficial acclimation hypothesis: when is physiological plasticity adaptive? Evolution, 56: 1863-1866. 